\title{
Investigating Factors Affecting Construction Workers Performance
}

\author{
Wibawa Prasetya ${ }^{*}$, Christine Natalia ${ }^{2}$, Stella $^{3}$ \\ ${ }^{1}$ Senior Lecturer, Industrial Engineering, Atma Jaya Catholic University of Indonesia, Indonesia \\ ${ }^{2}$ Lecturer, Industrial Engineering, Atma Jaya Catholic University of Indonesia, Indonesia \\ ${ }^{3}$ Research Fellow, Industrial Engineering, Atma Jaya Catholic University of Indonesia, Indonesia
}

Received: 29/05/2020 Accepted: 29/07/2020 Published: 20/09/2020

\begin{abstract}
Employee performance is fundamental to successful execution of construction project where it depends by internal and external factors. To increase employee performance, the organization should analyze the external factors that may reflect on employee performances. This research examines the relationship of work-life balance, mental workload and job satisfaction with the performance of construction employee. Data collection using questionnaires that have been tested for validity and relibiality and sampling technique using purposive sampling. The data processing was done by using NASA-TLX method to find out the mental workload and SEM (Structural Equation Modeling) method. The results showed that the mental work load negatively affect job satisfaction and employee performance, work-life balance positivetly affect job satisfaction and employee performance, and job satisfaction positively affect employee performance. The findings of the paper can be a guidance for construction companies to formulate strategy for increasing employee performances by adding the number of employees for the workload to be decreased, compressing work week for a balanced work-life and to promote the employees more frequently to increase job satisfaction.
\end{abstract}

keywords : Work-Life Balance, Mental Workload, Job Satisfaction, Employee Performance, SEM

\section{Introduction}

Construction project is very dependent on the performance of its employees, especially site-based employees. Professionals who work in the construction field such as engineers or architects have a very important role in order to faciliate effective communication between field workers and the organization and also solving problems in the workplace. In addition, these professional employees must coordinate with other project parties such as clients, designers, suppliers, sub-contractors and others (1). Therefore, it can be said that the performance of professional employees is fundamental to successful construction projects (1). Employees' performance in general is influenced by two factors, namely the willingness and abilities of employees to complete the works entrusted to them, as well as external factors from the companies (2), (3). One of the external factors from the organizations is work-life balance. Work-life balance is a condition where employees can balance work with other things or commitments such as family, hobbies, art, etc (4). Construction work has a very demanding work environment that is likely to have an adverse influence on its employees' life (5). Work in the construction field can put high pressure on workers due to deadlines, frequent meetings with shareholders and sub-contractors, problem solving on the ground which certainly causes long working hours and often has to work on holidays. Thus, construction companies need to take the initiative to support the work life balance experienced by their workers (6). Construction work is a complex job and often takes a very long working hours, especially among project staffs who work in the field office (site-based employees). The length of

Corresponding author: Wibawa Prasetya, Senior Lecturer, Industrial Engineering, Atma Jaya Catholic University of Indonesia, Indonesia. Email: wibawa.prasetya@atmajaya.ac.id working hours and frequent overtime can affect the workload experienced by employees, which based on previous research, excessive working hours can add to the burden it receives (7). Excessive workloads can cause errors such as misinformation or errors in carrying out the works that can be fatal to the continuity of the project (8). Thus, the organizations need to pay attention to the workloads experienced by its employees (9). These workloads consist of two; physical load and mental demand in which the physical burden is generally easier to identify while the mental burden is much more difficult to estimate. Based on previous research, the calculation of mental load has a high possibility in increasing the workers' productivity and safety conditions (8), (10).

Job satisfaction is also one of the external factors that need to be considered by the organizations. Job satisfaction is an emotional state that is both pleasant and unpleasant about the views of workers on their works (11). Based on research of job satisfaction in the US construction field, it is said that job dissatisfaction is a factor that triggers low productivity and causes increased costs and late completion of the project (12). Workers will be more productive and willing to stay in their careers for a longer period of time if they are satisfied with their jobs (13). The followings are some previous studies regarding the effects of work-life balance, mental workload and job satisfaction on employee performance. In the research of Romel G. Solis Carcano and Jose A. Gonzalez Fajardo (2) a research was conducted on the job satisfaction of construction employees in Mexico using the Minnesota Satisfaction questionnaire. The results of this study indicate that project employees in Mexico still feel dissatisfied with their jobs, especially for the salary levels. However, this study does not discuss further about the consequences of employee dissatisfaction with the employee's performance. Then in Renty Anugerah Mahaji Puteri and Zafira Nur Kamila 
Sukarna (14) carried out workload analysis at PT. ABC Construction using the CVL and NASA-TLX methods. From the results, it was found that the mental workload experienced by the engineer head office and project engineer was in the medium category and a proposal was made to divide the work effectively and efficiently between the engineer leader and the assistant engineer. However, this study does not discuss further about the impact of the workload experienced by employees on employee satisfaction and performance. Another research conducted by Jiayu Chen, John E. Taylor and Semra Comu regarding the measurement of mental workload in construction projects using electroencephalography (EEG) and NASA-TLX methods. This study only measured the mental workload and did not analyze the effect of this mental workload on the satisfaction and performance of its employees.

In the research of Helen Lingard, Kerry Brown, Lisa Bradley, Caroline Balley and Keith Townsend, a study concerning the improvement of the work life balance of workers in the construction industry was conducted. The result of this study is the compressing of work time in a week to 5 working days can improve the work-life balance experienced by workers. However, this study does not discuss further the effect of work-life balance on employee satisfaction and performance. In addition, research on worklife factors that affect the satisfaction of handicraft construction workers, no further analysis of the influence of the work-life factors on employee performance is carried out. Based on previous studies, it can be seen that there is no research that examines the influences of work life balance, mental workload and job satisfaction on employee performance in the construction field. Studies on job satisfaction in the construction industry have been conducted, but almost all of them have only analyze the effects on the laborers. This study aims to analyze the relationship between work-life balance, mental workload and job satisfaction with employee performance. The method used is structural equation model (SEM) to analyze the relationship between each variables.

\section{Model Building \& Research Hypotheses}

The following hypotheses are proposed:

1) The relationship between work-life balance and job satisfaction. In the study of Ganapathi and Gilang (15) on the effect of work-life balance on employee job satisfaction (case study at pt. bio farma persero) shows that work-life balance has a positive effect on job satisfaction, which means that employees with high work-life balance tend to have a high level of job satisfaction. Thus the following hypotheses are proposed:

H01 : Work-life balance has no effect on employee job satisfaction

H1: Work-life balance affects job satisfaction

2) The relationship between work-life balance and employee performance. In the research of Ischevell Vialara Saina, Riane Johnly Pio, and Wihelmina Rumawas entitled "The Effect of Work Life Balance and Compensation on Employee Performance on PT. PLN Suluttengo Manado Area" shows that work-life balance affects employee performance with a positive impact. Employees with a balance work-life tend to perform well. Thus the following hypotheses are proposed:

$\mathrm{H}_{2}$ : Work-life balance has no effect on employee performance

$\mathrm{H}$ 2: Work-life balance affects employee performance

3) The relationship between mental workload and job satisfaction
In the research of Yo and Surya (16) entitled "the influence of workload on job satisfaction with job stress as mediation variable" shows that workload has a negative effect on employee satisfaction. Employees with high mental workloads tend to be stressed out and not satisfied with their jobs. Thus the following hypotheses are proposed:

$\mathrm{HO}_{3}$ : Mental workload has no effect on job satisfaction H3: Mental workload affects job satisfaction

4) The relationship between mental workload and employee performance

In Ningsih's research (17) on the relationship between workload and job satisfaction with employee performance in eye hospital medial record installation Dr. Yep Yogyakarta" shows that workload affects employee perofrmance with a negative impact. Employees with high levels of mental workloads tend to perform poorly. Thus the following hypotheses are proposed:

$\mathrm{H}_{4}$ : Mental workload has no effect on employee performance H4: Mental workload affects employee performance

5) The relationship between job satisfaction and employee performance. In Ningsih's research (17) shows that job satisfaction affects employee performance with a positive impact. Employees with high level of job satisfaction tend to perform well. Thus the following hypotheses are proposed:

$\mathrm{H}_{3}$ : Job satisfaction has no effect on employee performance

H3: Job satisfaction affects employee performance

\section{Methodology}

In the research methodology, there are stages that must be carried out in order for the research's objectives to be achieved.

\subsection{Preparation}

At this stage, a field study was conducted, specifically a visit to one of the construction companies in Jakarta in order to find information about problems that occurred in the company and a preliminary study was conducted as a basis for determining the research topic. Literature studies were also conducted from books and research journals covering all variables, namely work-life balance, mental workload, job satisfaction, employee performance and the method used which is the SEM method.

\subsection{Research Design}

Based on the theories and previous researches, obtained the hypotheses that will be applied in research is obtained. In this study, there are exogenous and endogenous variables. Exogenous variables are independent variables that affect other variables. This exogenous variables consists of work-life balance and mental work load. Endogenous variables are dependent variables that are influenced by other variables in the study, namely job satisfaction and employee performance. The model research that iss being used in this research can be seen in Figure 1and the indicators and statements used in the questionare can be seen in Tabel 2. After designing the questionnaire, the preliminary questionnaire is distributed to test the validity and reliability of the statements. The initial questionnaire that got distributed were only for work-life balance, job satisfaction and employee performance questionnaires, while for the mental workload questionnaire, this research uses NASA-TLX questionnaire so there was no need for preliminary questionnaires. The preliminary questionnaire was distributed to 30 respondents / workers form one of the construction companies in Jakarta. 
Tabel 1: Operational Definition and Indicator

\begin{tabular}{|c|c|c|c|c|}
\hline $\begin{array}{l}\text { Latent } \\
\text { Variables } \\
\text { (Construct) }\end{array}$ & Operational Definition & Manifest Variables (Indicator) & $\begin{array}{l}\text { Indicato } \\
\text { r Code }\end{array}$ & Source \\
\hline \multirow{6}{*}{$\begin{array}{l}\text { Work-life } \\
\text { balance }\end{array}$} & \multirow{6}{*}{$\begin{array}{l}\text { "Employees can freely use their flexible } \\
\text { work hours to balance their job with other } \\
\text { commitments such as families, arts, studies } \\
\text { and to not only focus on their jobs (18) }\end{array}$} & Social balance & A1 & \multirow{6}{*}{$\begin{array}{l}\text { Rachman and } \\
\text { Savitri (2007) }\end{array}$} \\
\hline & & Physical balance & A2 & \\
\hline & & Intellectual balance & A3 & \\
\hline & & Career balance & A4 & \\
\hline & & Emotional balance & A5 & \\
\hline & & Spiritual balance & A6 & \\
\hline \multirow{5}{*}{$\begin{array}{l}\text { Mental } \\
\text { Workload }\end{array}$} & \multirow{5}{*}{$\begin{array}{l}\text { "Mental workload is the difference between } \\
\text { task demands with the maximum load } \\
\text { capacity of the mental demands of a person } \\
\text { in a motivated state" (19) }\end{array}$} & Task Demand & B1 & \multirow{5}{*}{$\begin{array}{l}\text { Hart and } \\
\text { Staveland } \\
(1988)\end{array}$} \\
\hline & & Effort & B2 & \\
\hline & & Performance & B3 & \\
\hline & & Time load & B4 & \\
\hline & & Psychological pressure & B5 & \\
\hline \multirow{5}{*}{ Job Satisfaction } & \multirow{5}{*}{$\begin{array}{l}\text { "A positive emotion that cimes form an } \\
\text { employee's job assessment or work } \\
\text { experience" (20) }\end{array}$} & Salary & $\mathrm{C} 1$ & \multirow{5}{*}{$\begin{array}{l}\text { Celluci et al. } \\
\text { (1978) }\end{array}$} \\
\hline & & Promotion & $\mathrm{C} 2$ & \\
\hline & & Colleagues & $\mathrm{C} 3$ & \\
\hline & & Supervisor & $\mathrm{C} 4$ & \\
\hline & & Occupation & $\mathrm{C} 5$ & \\
\hline \multirow{4}{*}{ Performance } & \multirow{4}{*}{$\begin{array}{l}\text { "The ability of employees to do certain } \\
\text { skills" (21) }\end{array}$} & Work quality & D1 & \multirow{4}{*}{$\begin{array}{l}\text { Dyne et al in } \\
\text { Mas'ud (2006) } \\
\text { and Diblitis } \\
(2010)\end{array}$} \\
\hline & & Work quantity & D2 & \\
\hline & & Working hours & D3 & \\
\hline & & Team work & D4 & \\
\hline
\end{tabular}

Tabel 2: Variables and Indicators for Questionnaire

\begin{tabular}{|c|c|c|c|}
\hline $\begin{array}{l}\text { Latent Variable } \\
\text { (Construct) }\end{array}$ & $\begin{array}{l}\text { Manifest Variable } \\
\text { (Indicator) }\end{array}$ & $\begin{array}{l}\text { Indicator } \\
\text { Code }\end{array}$ & Statement Items \\
\hline \multirow{11}{*}{$\begin{array}{l}\text { Work-life } \\
\text { balance }\end{array}$} & \multirow{2}{*}{ Social balance } & A.1.1. & I have a lot of time for my family \\
\hline & & A.1.2. & I have time to meet up with friends \\
\hline & Physical balance & $\begin{array}{l}\text { A.2.1. } \\
\text { A.2.2. }\end{array}$ & $\begin{array}{l}\text { The work provided is not tiring } \\
\text { I have time for excersicing }\end{array}$ \\
\hline & \multirow{3}{*}{ Intellectual balance } & A.3.1. & I have gotten a lot of knowledge since working in the company \\
\hline & & A.3.2. & I received various traning that are useful for works \\
\hline & & A.3.3. & I can manage my tasks without feeling pressured \\
\hline & Career balance & A.4.1. & My job would be useful in the development for my carreer \\
\hline & \multirow{3}{*}{ Emotional balance } & A.5.1. & I can divide my time to have some fun \\
\hline & & A.5.2. & I can use my own thoughts in finishing my tasks \\
\hline & & A.5.3. & I feel confident with my works \\
\hline & Spiritual balance & A.6.1. & I can divide my time for my religious needs \\
\hline \multirow{3}{*}{ Job Satisfaction } & \multirow{3}{*}{ Salary } & C.1.1 & My salary is compatible to the works that I do \\
\hline & & C.1.2. & My salary is enough to support my family \\
\hline & & C.1.3. & My company has provided many incentives for its employees \\
\hline
\end{tabular}

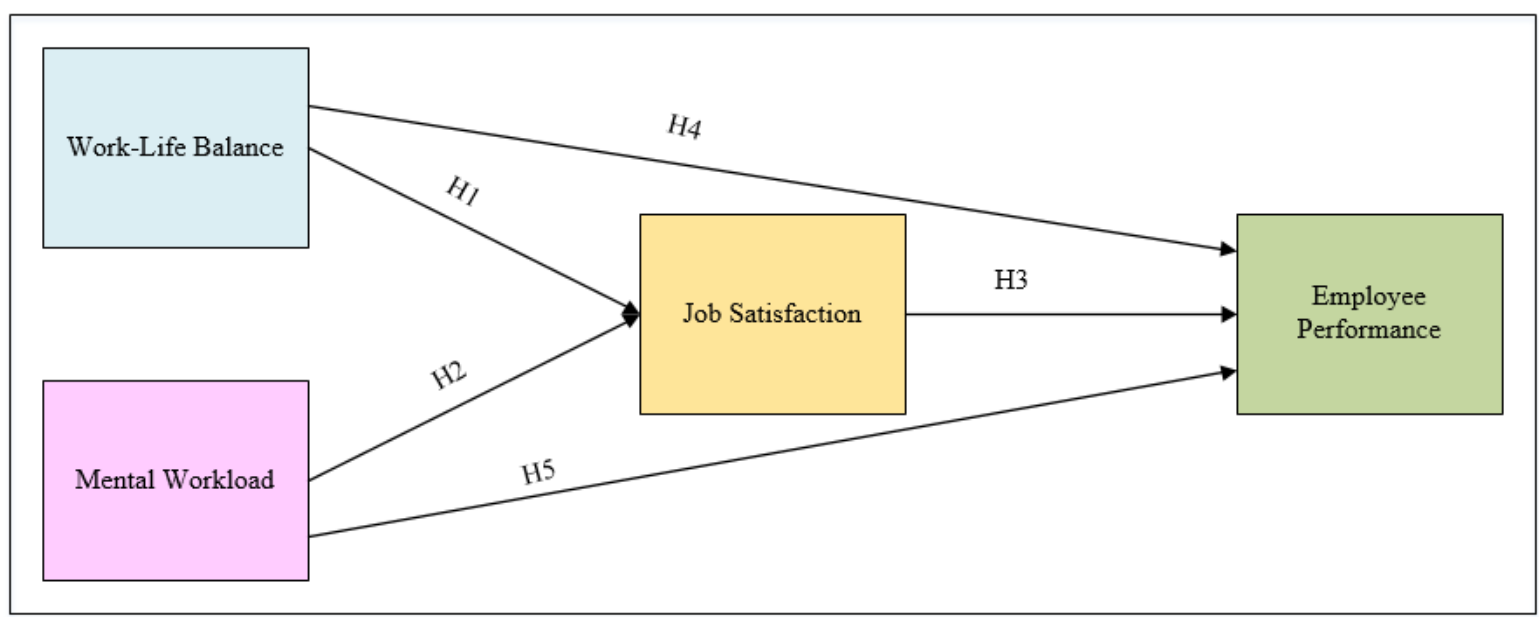

Figure 1: Model Research 
Tabel 2: Variables and Indicators for Questionnaire (Cont.)

\begin{tabular}{|c|c|c|c|}
\hline $\begin{array}{l}\text { Latent Variable } \\
\text { (Construct) }\end{array}$ & $\begin{array}{l}\text { Manifest Variable } \\
\text { (Indicator) }\end{array}$ & $\begin{array}{l}\text { Indicator } \\
\text { Code }\end{array}$ & Statement Items \\
\hline & \multirow{2}{*}{ Promotion } & C.2.1. & I feel satisfied with the promotion policies \\
\hline & & C.2.2. & The frequency of promotion is quite fast \\
\hline & \multirow{3}{*}{ Colleagues } & C.3.1. & I can communicate well with all my co-workers \\
\hline & & C.3.2. & I can work together with all my co-workers \\
\hline & & C.4.1. & I can communicate well with my supervisors \\
\hline & \multirow{2}{*}{ Supervisor } & C.4.2. & My supervisors always help me whenever I have troubles \\
\hline & & C.4.3. & $\begin{array}{l}\text { My supervisors always give me supports and evaluations of my } \\
\text { works }\end{array}$ \\
\hline & \multirow[b]{2}{*}{ Occupation } & C.5.1. & My work is interesting and fun \\
\hline & & C.5.2. & $\begin{array}{l}\text { I feel satisfied with the amount of responbilities that I receive in } \\
\text { doing my job }\end{array}$ \\
\hline \multirow{20}{*}{ Performance } & \multirow{5}{*}{ Work quality } & D.1.1. & The task done is meeting the company standards \\
\hline & & D.1.2. & Employee doing his responbilities as described in the job description \\
\hline & & D.1.3. & Employee follows the procedures and policies set by company \\
\hline & & D.1.4. & Employee can plan and organize his tasks \\
\hline & & D.1.5. & Employee works with high creativity \\
\hline & \multirow{6}{*}{ Work quantity } & & \\
\hline & & D.2.1. & Employee is willing to help other employees with excessive workload \\
\hline & & D.2.2. & Employee is willing to help the new employee \\
\hline & & D.2.3. & Employee's attendances at work exceeds the requirement \\
\hline & & D.2.4. & Employee is willing in doing extra effort to finish his task \\
\hline & & D.2.5. & $\begin{array}{l}\text { Employee is willing to replace other employees who are not present if } \\
\text { his job is done }\end{array}$ \\
\hline & \multirow{5}{*}{ Working hours } & D.3.1. & Employee always comes on time \\
\hline & & D.3.2. & Employee uses his break time according to the provisions \\
\hline & & D.3.3. & Employee uses his time in office / office-site to work \\
\hline & & D.3.4. & Employee uses his time efficiently \\
\hline & & D.3.5. & Employee uses his time effectively \\
\hline & \multirow{4}{*}{ Team Work } & D.4.1. & Employee is able to communicate with his co-workers \\
\hline & & D.4.2. & Employee is able to adapt in a team \\
\hline & & D.4.3 & Employee is able to work together in a team \\
\hline & & D.4.4. & Employee is willing to work with other employees \\
\hline
\end{tabular}

This is in accordance with Singarimbun and Efendi (22) and Sugiyono (23) which states that the minimum number of trial questionnaires is 30 respondents because with this minimum amount, the distribution of values will be closer to the normal curve.

\subsection{Data Collection}

The object of this research is one of the construction company projects in Jakarta with 150 respondents according to Hair et al. in Ghozali and Fuad (24) which states that the sample size for the SEM method with the maximum likelihood approach is $100-200$ samples.

\section{Results \\ 4.1 Validity Test}

Validity test is used to find out whether the questionnaire used for research has been accurate to measure existing research variables. Validity test is done using SPSS software by comparing the value $r$ count for each item statements with $r$ table where the statement item is said to be valid if the value $r$ count $>r$ table and $r$ is positive (24). $r$ table used is the $r$ table value with $\mathrm{df}=\mathrm{n}-2=30-2=28$, so that the $\mathrm{r}$ table value $=$ 0.361 . In this study, all validity test results have been valid.

\subsection{Reliability Test}

Reliability test is done to find out whether the questionnaire will have the same and consistent results if tested in other time. Statement items are said to be reliable if the Cronbach alpha value is $>0.60$ (24). In this study, it was found that the questionnaire was reliable.

\subsection{Respondents' Characteristics}

Based on table 3, it is known that the age range of 30-35 years has the largest percentage value of $38 \%$. Employees at this age are generally married and have children hence worklife balance is needed to maintain the family harmony. In addition, it is known that the majority of employees who work at this construction project is male $(88 \%)$ and generally married $(57 \%)$. This marital status can affect the level of work-life balance because employees who are married naturally want to have time for family so that if the level of work-life balance is low then it could affect job satisfaction and employee performance. 
Tabel 3: Respondents' Characteristics

\begin{tabular}{|c|c|c|c|}
\hline Criteria & Category & Total & Percentage \\
\hline \multirow[t]{5}{*}{ Age } & $18-23$ years old & 20 & $13 \%$ \\
\hline & $24-29$ years old & 23 & $15 \%$ \\
\hline & $30-35$ years old & 56 & $37 \%$ \\
\hline & $36-41$ years old & 19 & $13 \%$ \\
\hline & $>41$ years old & 32 & $21 \%$ \\
\hline Total & & 150 & $100 \%$ \\
\hline \multirow{2}{*}{ Sex } & Men & 132 & $88 \%$ \\
\hline & Women & 18 & $12 \%$ \\
\hline Total & & 150 & $100 \%$ \\
\hline \multirow[t]{2}{*}{ Marital Status } & Single & 64 & $43 \%$ \\
\hline & Married & 86 & $57 \%$ \\
\hline Total & & 150 & $100 \%$ \\
\hline \multirow[t]{6}{*}{ Education Degree } & Middle school or equivalent & 0 & $0 \%$ \\
\hline & High school or equivalent & 26 & $17 \%$ \\
\hline & Associate Degree / Diploma or equivalent & 4 & $3 \%$ \\
\hline & Bachelor degree or equivalent & 96 & $64 \%$ \\
\hline & Master degree or equivalent & 24 & $16 \%$ \\
\hline & Others & 0 & $0 \%$ \\
\hline Total & & 150 & $100 \%$ \\
\hline \multirow[t]{4}{*}{ Period of Working } & $<1$ year & 7 & $5 \%$ \\
\hline & $1-4$ years & 84 & $56 \%$ \\
\hline & $5-9$ years & 29 & $19 \%$ \\
\hline & $>9$ years & 30 & $20 \%$ \\
\hline Total & & 150 & $100 \%$ \\
\hline
\end{tabular}

From the results of the respondents' data it is known that the majority employees in this construction project have a bachelor degree or equivalent $(64 \%)$ with the majority have been working for $1-4$ years $(56 \%)$.

\subsection{Mental Workload Calculation}

The calculation of the average weighted workload is conducted for each divition as follows in table 4. To calculate the optimal number of employees, the total weighted workload value for each division is divided by the average workload. The average workload used is 60 , because the value of 60 is the upper limit of the moderate / optimal workload group, but not included in the high workload group. The result of the optimal number of employees calculation is in table 5 .

Table 4: Mental Workload Result

\begin{tabular}{lll}
\hline Divition & $\begin{array}{l}\text { Weighted Workload } \\
\text { Average }\end{array}$ & Category \\
\hline Engineering & 67,3 & High \\
\hline Quality Control & 72,71 & High \\
\hline Quantity Surveyor & 76,98 & High \\
\hline
\end{tabular}

Table 5: Optimal Number of Employees

\begin{tabular}{lll}
\hline Divition & $\begin{array}{l}\text { The number of } \\
\text { operatosr right } \\
\text { now }\end{array}$ & $\begin{array}{l}\text { The number } \\
\text { of proposed } \\
\text { operators }\end{array}$ \\
\hline Engineering & 79 & 89 \\
\hline Quality Control & 56 & 68 \\
\hline Quantity Surveyor & 15 & 20 \\
\hline
\end{tabular}

From the results of Table 4. it was found that the average mental workload of each division was included in the high category, thus requiring an increase in the number of employees to achieve an optimal number of employees.
The addition of the employees aims to avoid excessive mental workload which can cause errors that can harm the company. This is also supported by the results of this research hypothesis, which states that workload affects work satisfaction and employee performance. By adding employees to each division in accordance with the proposed amount, the employee will get an optimal workload which could increase job satisfaction and employee performance that can benefit the company.

\subsection{Research Model Analysis}

Based on table 6 , in the initial estimation results there are 10 parameters that are fit and 7 parameters that are not fit. According to Wijanto (25), the suitability assessment of the model was assessed based on the number of model sizes that could be fulfilled by the suitability of the research model. The more matched target values are met the better the model or in other words the GOF parameter must be fit> 50\%. In this study the parameters that meet the target of $58.82 \%$ can be said that the model is fit. However, modifications can be made to get the maximum GOF results. From the results of the modification, it was found that there was a change in RMSEA where the initial RMSEA was 0.073 to 0.039 so that it became fit. Besides that, $\mathrm{P}$ also changes, from 0 to 1 so it becomes fit. From the results of the modification, it can be seen that the difference in the number of fit increases even though only 1 differs so that the fit parameter is 11 and the parameter does not fit 6 so that the parameters that meet the target are $64.71 \%$ so that it can be said that the model is fit. From the results of table 7 , it was found that all variables were reliable because composite reliability> 0.70 and extracted variance> 0.5 (25). Although the satisfaction and performance variables have a extracted variance smaller than 0.50 , it can still be said to be a reliable model. 


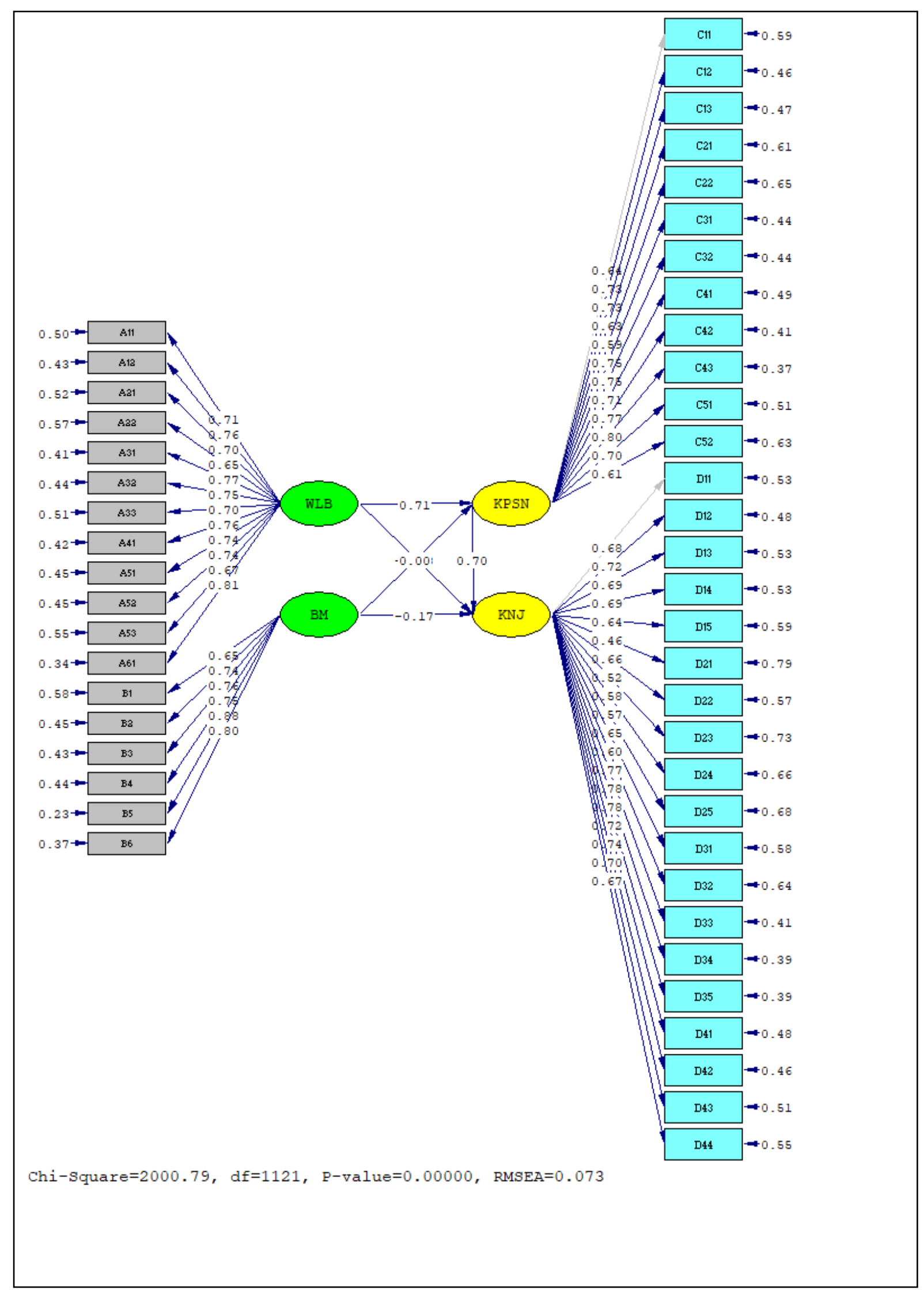

Figure 2: Path Diagram Standardized Solution 


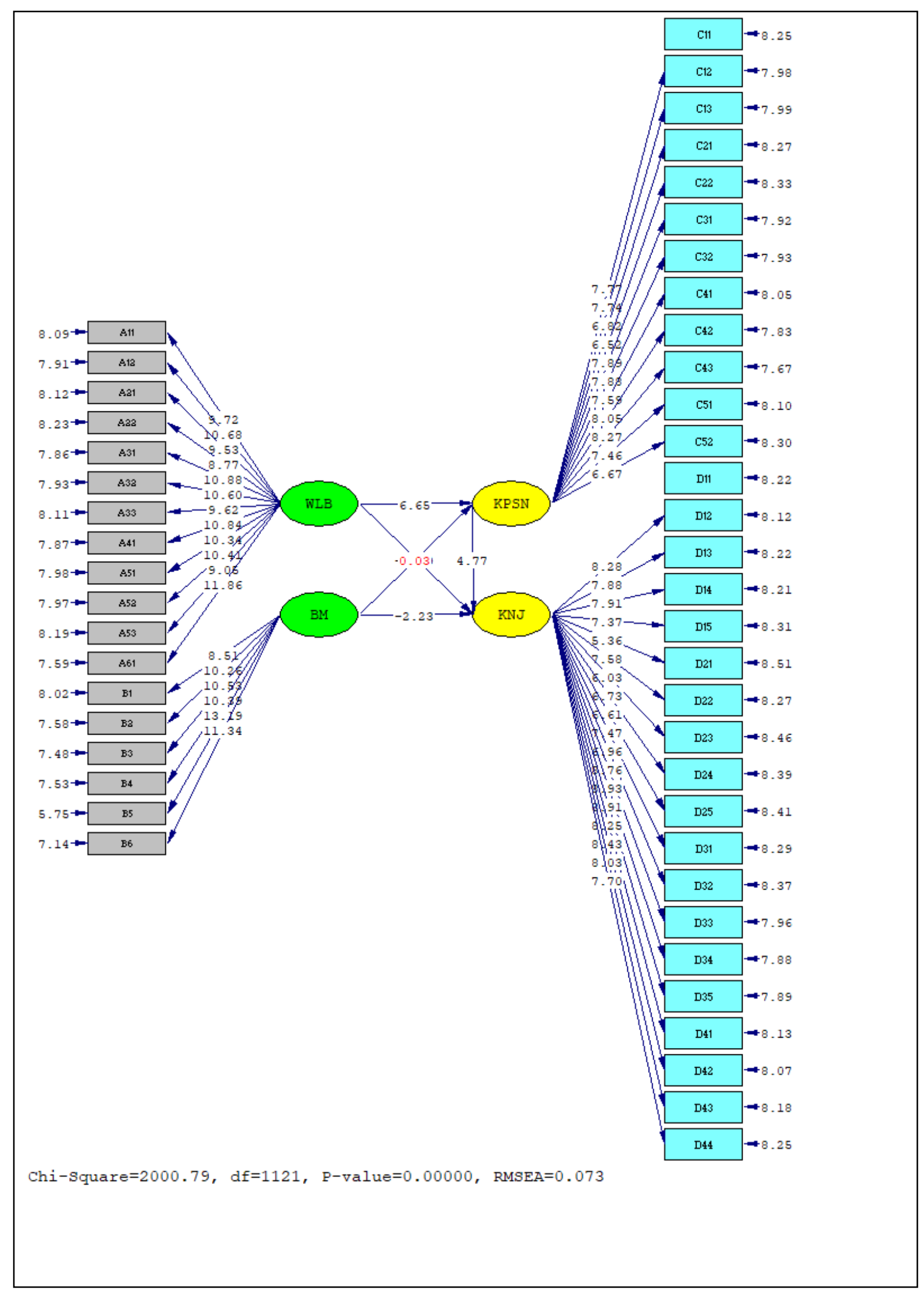

Figure 3: Path Diagram T-Value 
Tabel 6: Goodness of Fit

\begin{tabular}{|c|c|c|c|}
\hline GOF Category & Parameter & Estimation Result & Modification Result \\
\hline \multirow{2}{*}{$\begin{array}{l}\text { Chi-Square } \\
\mathrm{P} \text {-Value }\end{array}$} & Small value & 1954,25 & 1438,40 \\
\hline & $p>0,05$ & 0 & 0 \\
\hline $\mathrm{NCP}$ & Small value & 879,79 & 240,24 \\
\hline RMSEA & RMSEA $\leq 0,05$ & 0,073 & 0,039 \\
\hline $\mathrm{P}$ & $p>0,05$ & 0 & 1,00 \\
\hline \multirow{3}{*}{ ECVI } & Lower than Saturared & $\mathrm{ECVI}=14,82$ & $\mathrm{ECVI}=10,79$ \\
\hline & Model and & Saturated $=16,44$ & Saturated $=16,44$ \\
\hline & Independence Model & Independence $=188,64$ & Independence $=188,64$ \\
\hline \multirow{3}{*}{ AIC } & \multirow{3}{*}{$\begin{array}{l}\text { Lower than Saturared } \\
\text { \&Independence Model }\end{array}$} & $\mathrm{AIC}=2208,79$ & $\mathrm{AIC}=1608,24$ \\
\hline & & Saturated $=24500$ & Saturated $=24500$ \\
\hline & & Independence $=28106,99$ & Independence $=28106,99$ \\
\hline \multirow{3}{*}{ CAIC } & \multirow{3}{*}{$\begin{array}{l}\text { Lower or near Saturared } \\
\text { and Independence }\end{array}$} & CAIC $=2625,89$ & CAIC $=2181,76$ \\
\hline & & Saturated $=7363,03$ & Saturated $=7363,03$ \\
\hline & & Independence $=28303,51$ & Independence $=28303,51$ \\
\hline NFI & $\geq 0,90$ & 0,93 & 0,95 \\
\hline NNFI & $\geq 0,90$ & 0,97 & 0,99 \\
\hline CFI & $\geq 0,90$ & 0,97 & 0,99 \\
\hline IFI & $\geq 0,90$ & 0,97 & 0,99 \\
\hline RFI & $\geq 0,90$ & 0,93 & 0,94 \\
\hline $\mathrm{CN}$ & $\geq 200$ & 95,09 & 124,60 \\
\hline RMR & Standardized $\leq 0,05$ & 0,066 & 0,058 \\
\hline GFI & $\geq 0,90$ & 0,65 & 0,73 \\
\hline AGFI & $\geq 0,90$ & 0,61 & 0,70 \\
\hline
\end{tabular}

Tabel 7: Reliability dan Variance Extracted

\begin{tabular}{lll}
\hline & Composite Reliability & Variance Extracted \\
\hline WLB & 0,9321 & 0,5345 \\
\hline BM & 0,8935 & 0,585 \\
\hline KPSN & 0,9211 & 0,4954 \\
\hline KNJ & 0,93815 & 0,4479 \\
\hline
\end{tabular}

\section{6 $R^{2}$ value / Squared Multiple Correlation}

a. $\mathrm{R}^{2}$ value of Work-Life Balance and Workload $\rightarrow$ Job Satisfaction is 0.68 , which means that $68 \%$ of the variance in the work satisfaction variable is explained by the work-life balance and workload variables while the other $32 \%$ is explained by variables other than work-life balance and workload.

b. $\mathrm{R}^{2}$ value of Job Satisfaction, Work-Life Balance and Workload $\rightarrow$ Performance is 0.66 , which means that $66 \%$ of the variance in employee performance variables is explained by the variables of job satisfaction, work-life balance and workload while the other $34 \%$ are explained by variables other than job satisfaction, work-life balance and workload.

\subsection{Research Hypotheses Analysis}

This hypothesis testing is done by comparing the $t$ value of the results of the structural equation model (SEM) with the $\mathrm{t}$ table value at the $5 \%$ significance level $(\mathrm{t}$ table $=1.96)$. $\mathrm{H} 0$ is accepted if the $t$ value is smaller than 1.96 or greater than 1.96.

1) The relationship between Work-Life Balance and Job Satisfaction

Hypotheses:
$\mathrm{H}_{1}$ : Work-life balance has no effect on employee job satisfaction

H1: Work-life balance affects job satisfaction

Basic decision making:

If the probability value is $>0.05$ or $\mathrm{t}$ count $<\mathrm{t}$ table or $-\mathrm{t}$ count> - $\mathrm{t}$ table, then $\mathrm{H} 01$ is accepted.

If the probability value is $<0.05$ or $t$ counts $>t$ table or $-t$ counts <- $\mathrm{t}$ table, then $\mathrm{H} 01$ is rejected.

The $\mathrm{t}$ table value for alfa $=0.05$ is 1.96 .

Decision:

The value of $t$ count work-life balance against job satisfaction $>\mathrm{t}$ table $(6.65>1.96)$ then reject $\mathrm{H} 01$ which means that the work-life balance affects employee job satisfaction

2) The relationship between Work-Life Balance with Employee Performance

Hypotheses:

$\mathrm{HO}_{2}$ : Work-life balance has no effect on employee performance

H2: Work-life balance affects employee performance

Basic decision making:

If the probability value is $>0.05$ or $t$ count $<\mathrm{t}$ table or $-\mathrm{t}$ count $>$ - $\mathrm{t}$ table, then H01 is accepted.

If the probability value is $<0.05$ or $t$ counts $>t$ table or $-t$ counts <- $\mathrm{t}$ table, then $\mathrm{H} 01$ is rejected.

The $\mathrm{t}$ table value for alfa $=0.05$ is 1.96 .

Decision:

The value of $\mathrm{t}$ counts work-life balance against employee performance <t table $(0.03<1.96)$ then accept $\mathrm{H} 02$ which means that work-life balance does not affect employee performance significantly.

3) The relationship between mental workload and job satisfaction

Hypotheses: 
$\mathrm{H}_{3}$ : Mental workload has no effect on job satisfaction

H3: Mental workload affects job satisfaction

\section{Basic decision making:}

If the probability value is $>0.05$ or $\mathrm{t}$ count $<\mathrm{t}$ table or $-\mathrm{t}$ count $>-\mathrm{t}$ table, then $\mathrm{H} 01$ is accepted.

If the probability value is $<0.05$ or $t$ counts $>\mathrm{t}$ table or $-\mathrm{t}$ counts <- $\mathrm{t}$ table, then $\mathrm{H} 01$ is rejected.

The $t$ table value for alfa $=0.05$ is 1.96 .

\section{Decision:}

The value of $t$ counts workload on job satisfaction <-t table ($2.08<-1.96)$ then reject $\mathrm{H} 03$, which means that workload has an effect on employee job satisfaction.

4) The relationship between mental workload and employee performance

\section{Hypotheses:}

$\mathrm{H}_{4}$ : Mental workload has no effect on employee performance

H4: Mental workload affects employee performance

Basic decision making:

If the probability value is $>0.05$ or $\mathrm{t}$ count $<\mathrm{t}$ table or $-\mathrm{t}$ count $>$ - $t$ table, then $\mathrm{H} 01$ is accepted.

If the probability value is $<0.05$ or $t$ counts $>\mathrm{t}$ table or $-\mathrm{t}$ counts <- $\mathrm{t}$ table, then $\mathrm{H} 01$ is rejected.

The $t$ table value for alfa $=0.05$ is 1.96 .

\section{Decision:}

The value of $t$ counts the workload on employee performance $<-t$ table $(-2.23<-1.96)$ then reject $\mathrm{H} 04$, which means that workload affects employee performance.

5) The relationship between job satisfaction and employee performance

Hypotheses:

H05: Job satisfaction has no effect on employee performance

H5: Job satisfaction affects employee performance

\section{Basic decision making:}

If the probability value is $>0.05$ or $\mathrm{t}$ count $<\mathrm{t}$ table or $-\mathrm{t}$ count $>$ - $t$ table, then $\mathrm{H} 01$ is accepted.

If the probability value is $<0.05$ or $t$ counts $>t$ table or $-\mathrm{t}$ counts <- $\mathrm{t}$ table, then $\mathrm{H} 01$ is rejected.

The $\mathrm{t}$ table value for alfa $=0.05$ is 1.96 .

Decision:

$\mathrm{T}$ value calculated job satisfaction on employee performance> t table (4.77> 1.96) then reject H05 which means that job satisfaction affects employee performance.

\section{Discussion \\ 5.1 Theoritical Implication}

From the results of hypothesis 1, it is known that work-life balance affects employee job satisfaction where the higher the work-life balance or the more balanced the employee's life between work and personal life, the more satisfied the employee will be at work. This is in accordance with the research of Ganapathi and Gilang (15) and Rani (26) which shows that work-life balance is positively and significantly related to job satisfaction directly. The study of Francis (27) of civil engineers reported to have higher commitment, job satisfaction and lower turnover intention when the organization supports the work-life balance initiatives. The research of Lingard, et al (28) shows that construction workers are satisfied with the compressed working week (5-days per week) because on the weekend they can have their time with family / friends. From the results of hypothesis 2, it is known that the work-life balance does not significantly influence employee performance. This is supported by research conducted by Cahyo Utomo, Indi Djastuti and Mahfudz (29) which obtained results that work-life balance has a positive effect on employee performance but not significant. This is also in line with Kim's (30) statement that work-life balance has an indirect effect on performance through commitment variables. Based on Kim's research, work-life balance has no direct effect on performance, but work-life balance affects employee commitment, where the work-life balance that is fulfilled will have a positive influence on employee commitment to the company. Grover and Crooker (31) found that employees in companies with work-life balance benefits had higher levels of commitment to the organization. Employees who have a high commitment to their company will improve their performance in order to provide a high contribution to the company, in accordance with the opinion of Mathieu and Zajac (32); Mayer and Schoorman (33); and Swailes (34).

From the results of hypothesis 3 , it is known that the workload has a negative effect on job satisfaction. This means that a high workload will cause job satisfaction to decrease and vice versa, a low workload will lead to increased job satisfaction. This is consistent with the research of Mustapha and Ghee (35) which states that job satisfaction is influenced by daily workload, where employees are more satisfied when given a low workload. Construction industry has complicated and demanding task with high pressures, deadlines, and tight schedules. Mental distress can result from a mismatch between job demands and employee's latitude in decision making (36). Employees that are constantly under mental stress can develop mental health problems such as depression and anxiety, which may not only compromise construction worker satisfaction level, but may distract workers' attention from their job and result in accidents (37).

From the results of hypothesis 4 , it is known that the workload has a negative effect on employee performance. This is consistent with Ningsih's (38) study which states that workloads have a negative relationship or are inversely related to employee performance. Employees who have a high workload tend to perform poorly. Construction tasks require a great amount of physiological effort (10) and create a heavy mental load (8), (9). Mental fatigue results in effort disinclination, reduction in efficiency and alertness, and impaired mental performance (39). Mental fatigue also results in lack of focus and diligence in performing task appropriately (40). From the results of hypothesis 5 , it is known that job satisfaction has a positive effect on employee performance. This is supported by Ningsih's (38) research which states that job satisfaction is directly proportional to employee performance. Employees who are satisfied with their work tend to have good performance. In the research of Leung et al. (41) on job satisfaction of construction craft workers, it is found that improved job satisfaction can enhance workers' participation on the job, implementation of decided project goals and team cohesion, thus leading to better overall performance of a project. Kazaz et al. (42) did a research about variables that affect construction laborer productivity and found that job satisfaction is one of the critical sociopsychological factors that keep workers motivated.

\subsection{Managerial Implication}

Based on the results of the research that has been done, construction companies need to pay attention to the workload experienced by their workers because of excessive workload can lead to reduced effort by workers, decreased efficiency and agility and disrupt performance (39). In addition, mental overload can cause a loss of work focus and the ability to do work properly (40). Therefore construction companies need to divide the work between employees equally and add the number of workers so that they can ease the work.

From the results of the study, it was found that the work-life balance did not significantly influence employee performance. However, work-life balance has a significant 
effect on job satisfaction and job satisfaction has a significant effect on employee performance. So that construction companies still have to pay attention to the work-life balance of their employees in order to increase job satisfaction which then encourages employee performance to be maximum. Companies can narrow the workday of the week and increase work time in a day (28). Increasing job satisfaction can be done by increasing the frequency of promotion of employees, namely evaluating the performance of their employees. This performance appraisal should be carried out by superiors who hold employees directly below it so that the assessment can be carried out objectively. From the results of the performance appraisal, the company can consider promotion for employees with good performance so that other employees are motivated to work optimally.

\section{Conclusion}

Project employee performance is very important to be considered by the company because employee performance is the foundation of successful construction projects. Thus, factors that affect employee performance are important to be considered by the company. From the results of the research, it was found that work-life balance has a significant effect on employee job satisfaction, but not significant on employee performance, mental workload has a significant effect on employee satisfaction and performance, and job satisfaction has a significant effect on the performance of construction employees. This study has limitations where the majority of employees who fill out the new questionnaire have work experience for 1-4 years so that they cannot be said to have enough experience. So that the next research can be done for employees who have experienced work that is 5 years and above. Subsequent research should conduct interviews to validate the results of the research to the workers so as to avoid biased results. In addition, further research can further examine the factors that influence the work-life balance and mental workload of construction employees.

\section{Ethical issue}

Authors are aware of, and comply with, best practice in publication ethics specifically with regard to authorship (avoidance of guest authorship), dual submission, manipulation of figures, competing interests and compliance with policies on research ethics. Authors adhere to publication requirements that submitted work is original and has not been published elsewhere in any language.

\section{Competing interests}

The authors declare that there is no conflict of interest that would prejudice the impartiality of this scientific work.

\section{Authors' contribution}

All authors of this study have a complete contribution for data collection, data analyses and manuscript writing.

\section{References}

1. Solis, C.R., et al. Job Satisfaction of Construction Professionals: Case Study in Eastern Mexico. Journal of Construction. 2015;14(3):64-71.

2. Cooper, M. Changing Employee Values: Deepening Discontent? Harvard Business Review. 1979;57(1):117-125.

3. Friend, K.E. and Burns, L.R. "Sources of Variation in Job Satisfaction: Job Size Effects in a Sample of The U.S. Labor Force. Personnel Psychology. 1977;30(4):589-605.

4. Frame, P. and Hartog, M. From Rhetoric to Reality : Into The Swamp od Ethical Practice. Implementing Work-Life Balance. Business Ethics. A Europe Review. 2003;12 (4):358-367.
5. Lingard, H. and Francis, V. The Work-Life Experiences of Office and Site-Based Employees in The Australian Construction Industry. Journal of Construction Engineering and Management. 2004;22:991-1002.

6. Emily, J.M. Employee Preferences for Work-Life Balance Initiative In A Large New Zealand Construction Company. Theses, Unitec, New Zealand. 2010.

7. Tarwaka. Industrial Ergonomic Basic Knowledge of Ergonomic and Applications in Workplace. Second Edition, Harapan Press, Surakarta. 2015.

8. Dadi, G.B. et al. Cognitive Workload Demands Using 2D and 3D Spatial Engineering Information Formats. Journal Construction, Engineering, Management. 2014;140(5):04014001-1 04014001-8.

9. Chen, J., John E. T., Semra, C. Assessing Task Mental Workload in Construction Projects: A Novel Electroencephalography Approach. Journal of Construction Engineering and Management. 2017. 10.1061/(ASCE)CO.1943-7862.0001345, 04017053-1 04017053-13

10. Abdelhamid, T.S., and Everett, J.G. Physiological Demands During Construction Work. Journal Construction, Engineering, Management. 2002;128(5):427-437.

11. Côté, S. and Morgan, L.M, A longitudinal analysis of the association between emotion regulation, job satisfaction, and intentions to quit. J. Organiz. Behav. 2002;23:947-962. doi:10.1002/job.174.

12. Borcherding, J.D. and Oglesby, C.H. Construction Productivity and Job Satisfaction. Journal Construction Division. 1974;100(3):413-431.

13. Bedeian, A.G., Ferris, G.R., and Kacmar, K.M. Age, Tenure, and Job Satisfaction: A Tale of Two Perspectives." Journal Vocational Behaviour. 1992;40(1):33-48.

14. Putri Handayani, Widiarti Hanum, Mayumi Nitami, Helmy Faizal. Factors relating to work stress in production of unit worke rs in pt. indo surya kencana. International Journal of Psychosocial Rehabilitation. 2020; 24: 2772-2777.

15. Ganapathi, I Made Devan and Gilang, Alini. Work Life Balance Effects on Employee Satisfaction (Study Case PT. Biro Farma Persero). Jurnal Ecodemica. 2016;4(1):125-135.

16. Yo, Putu Melati Purbaningrat dan Ida Bagus Ketut Surya. The Effect of Workload on Job Satisfaction with Work Stress as Mediation Variable. E-Jurnal Manajemen Unud. 2015;4(5):11491165 .

17. Ningsih, Kori Puspita. The Relationship of Workload and Job Satisfaction on Employee Performance in Medical Instalation Dr. Yap. Eye Hospital Yogyakarta. Final Project. Muhammadiyah Surakarta University, Surakarta. 2013.

18. Galea, Christopher \& Houkes, Inge \& Rijk, Angelique. An insider's point of view: How a system of flexible working hours helps employees to strike a proper balance between work and personal life. International Journal of Human Resource Management. 2014;25. 10.1080/09585192.2013.816862.

19. Ghozali, I. and Fuad. Structural Equation Modeling: Structural Equation Modeling: Theory, Concept, and Application. Universitas Diponegoro Publishing, Semarang. 2005.

20. Utomo, Cahyo. et al. The Effect of Work Life Balance on Work Stress With Implication to Employee Performance (Study Case BPK Representative Middle Java). Masters Thesis, Diponegoro University, Semarang. 2016.

21. Saina, Ischevell Vialara. et al. The Effect of Work Life Balance and Compensation on Employee Performance in PT. PLN (Persero) Suluttenggo Manado. Jurnal Administrasi Bisnis. 2016;4(3):1-9.

22. Singarimbun and Effendi. Methodology Research Survey. Revised Edition, PT. Pustaka LP3ES, Jakarta. 1995.

23. Sugiyono. Methodology Educational Research Quantitative Approach, Qualitative, and R\&D. Alfabeta, Bandung. 2013.

24. Ghozali, I. Analysis Multivariate Application With SPSS Program. Universitas Diponegoro Publishing, Semarang. 2001.

25. Wijanto, Setyo H. Structural Equation Modeling. Graha Ilmu, Yogyakarta. 2008

26. Rani, Sakthi Vel and Dr., Kamalanabban and Mariappan, Selvarani, Work/Life Balance Reflections on Employee Satisfaction (August 1, 2010). Serbian Journal of Management. 2011;6 (1):pp. 85-96. 
27. Francis, V. et al. Work-Family and Construction: Public and Private Sector Differences. Journal of Management in Engineering. 2013;29(4):392-399.

28. Lingard, H. et al. Improving Employee's Work-Life Balance in the Construction Industry: Project Alliance Case Study. Journal of Construction Engineering and Management. 2007;133(10):807-815.

29. Moedy, D.M.R. Work-Life Balance Analysis, Willingness to Left Organization, Burnout And Job Satisfaction on Lecturer of Atma Jaya Yogyakarta University. Final Project. Atma Jaya Yogyakarta University, Yogyakarta. 2013.

30. Kim. Work-Life Balance and Employees' Performance: The Mediating Role of Affective Commitment. Global Business and Management Research: An International Journal. 2014;6(1):3751.

31. Grover, S. L. and Crooker, K. L. Who appreciates familyresponsive human resource policies? The impact of familyfriendly policies on the organizational attachment of parents and non-parents. Pers. Psychol. 1995. 48, 271-288.

32. Mathieu, J.E. and Zajac, D. A Review and Meta-Analysis of The Antecedents, Correlates, and Consequences of Organizational Commitment. Psychological Bulletin. 1990;108(2):171-194.

33. Mayer, R.C. and Schoorman, F.D. Predicting Participation and Production Outcomes Through A Two-Dimensional Model of Organizational Commitment. Academy of Management Journal. 1992;35(3):671-684.

34. Swailes, S. Commitment to Change: Profiles of Commitment and In-Role Performance. Personal Review. 2004;33(2):187-204.

35. Mustapha, N. and Ghee, W.Y. Examining Faculty Workload as Anttecedent of Job Satisfaction Among Academic Staff of Higher Public Education in Kelantan, Malaysia. Journal Business and Management Horizons. 2013;1(1).

36. Karasek, R. A., Jr. Job demands, job decision latitude, and mental strain: Implications for job redesign. Administrative Sci. Q. 1979;24(2):285-308.

37. Boschman, J., Van der Molen, H., Sluiter, J. and Frings-Dresen, M. Psychosocial work environment and mental health among construction workers. Appl. Ergon. 2013;44(5):748-755.

38. Mitropoulos, P., and Guillama, V. Analysis of Residential Framing Accidents, Activities, and Task Demands. Journal Construction, Engineering, Management. 2010;136(2);260-269.

39. Zhao, C., Zheng. C., Zhao, M., Tu, Y., and Liu, J. Multivariate Autoregressive Models and Kernel Learning Algorithms for Classifying Driving Mental Fatigue based on Electroencephalographic.. Expert Syst. Appl. 2011;38(3);18591865 .

40. Mitropoulos, P., and Memarian, B. Task Demands in Masonry Work: Sources, performance implications, and management strategies. J. Consutrction Engineering Management. 2012. 10.1061/(ASCE)CO.1943-7862.0000586, 581-590.

41. Kazaz A, Ulubeyli S. Drivers of productivity among construction workers: a study in a developing country. Build Environ. 2007. 42(5):2132-2140. 